Archived version from NCDOCKS Institutional Repository http://libres.uncg.edu/ir/asu/

\title{
Appalachľan
}

B O O N E, N O R T H C A R O L I N A

\section{Determinants of Plasma Retinol Concentrations of Middle-Aged Women in Rural China}

\author{
Authors: MARTIN M. ROOT, JIFAN HU, LANI S. STEPHENSON, \\ ROBERT S. PARKER, AND T. COLIN CAMPBELL,
}

\begin{abstract}
The purpose of this study was to assess the correlates and possible determinants of plasma vitamin A among middle-aged women in rural China. The vitamin A adequacy of the different diets at the five widely varying survey sites was also assessed. Patterns of correlations among dietary and biochemical measurements were strikingly different from previous studies in Western subjects. Plasma B-carotene was uncorrelated with B-carotene intake even after adjusting for potential confounders. In counties with low preformed vitamin A intake, plasma retinol correlated with plasma copper $(\mathrm{P}=0.007)$, which in turn was correlated with dietary intake of copper $(\mathrm{P}=0.007)$. In these counties plasma retinol was correlated with plasma $\mathrm{B}$-carotene $(\mathrm{P}=$ $0.001)$ and was increased $10 \%$ in women in the first $2 \mathrm{y}$ of menopause $(\mathrm{P}=0.028)$. Plasma retinol and $\mathrm{C}$-reactive protein levels are inversely correlated $(\mathrm{r}=-0.15, \mathrm{P}<0.001)$, indicating that vitamin A status and inflammatory response may be related but the causal direction is unknown. Despite low intake of vitamin A (county averages of $13-78 \%$ of recommended daily allowance [RDA]), and particularly of preformed vitamin A, only $3 \%$ of these women had plasma retinol levels below 0.7 $\mu, \mathrm{mol} / \mathrm{L}$, considered to indicate possible marginal deficiency. Plasma levels of retinol and Bcarotene were more influenced by intrinsic factors such as menopause, lipid status, retinol requirements, and possibly copper status and inflammation than by extrinsic factors such as diet and lifestyle
\end{abstract}

MARTIN M. ROOT, JIFAN HU, LANI S. STEPHENSON, ROBERT S. PARKER, AND T. COLIN CAMPBELL(1999) Determinants of Plasma Retinol Concentrations of Middle-Aged Women in Rural China. Nutrition (Vol. 15, No. 2, 1999) (ISSN 0899-9007) 


\title{
Determinants of Plasma Retinol Concentrations of Middle-Aged Women in Rural China
}

\author{
MARTIN M. ROOT, MS,* JIFAN HU, PHD, $\dagger$ LANI S. STEPHENSON, PHD, + \\ ROBERT S. PARKER, PHD, $\ddagger$ AND T. COLIN CAMPBELL, PHD $\ddagger$
}

\begin{abstract}
The purpose of this study was to assess the correlates and possible determinants of plasma vitamin A among middle-aged women in rural China. The vitamin A adequacy of the different diets at the five widely varying survey sites was also assessed. Patterns of correlations among dietary and biochemical measurements were strikingly different from previous studies in Western subjects. Plasma $B$-carotene was uncorrelated with $B$-carotene intake even after adjusting for potential confounders. In counties with low preformed vitamin A intake, plasma retinol correlated with plasma copper $(P=0.007)$, which in turn was correlated with dietary intake of copper $(P=0.007)$. In these counties plasma retinol was correlated with plasma $B$-carotene $(P=0.001)$ and was increased $10 \%$ in women in the first $2 \mathrm{y}$ of menopause $(P=0.028)$. Plasma retinol and C-reactive protein levels are inversely correlated $(r=-0.15, P<0.001)$, indicating that vitamin A status and inflammatory response may be related but the causal direction is unknown. Despite low intake of vitamin A (county averages of $13-78 \%$ of recommended daily allowance [RDA]), and particularly of preformed vitamin A, only $3 \%$ of these women had plasma retinol levels below $0.7 \mu$, mol/L, considered to indicate possible marginal deficiency. Plasma levels of retinol and $B$-carotene were more influenced by intrinsic factors such as menopause, lipid status, retinol requirements, and possibly copper status and inflammation than by extrinsic factors such as diet and lifestyle.
\end{abstract}

Key words: B-carotene, plasma, retinol, copper, C-reactive protein, women, menopause 
TABLE I.

LOCATION, DIETARY PATTERNS, AND COUNTY MEANS OF SELECTED NUTRIENT INTAKES OF WOMEN IN FIVE RURAL COUNTIES

\begin{tabular}{|c|c|c|c|c|c|}
\hline County & $\mathrm{CD}$ & $\mathrm{LC}$ & SB & WA & YA \\
\hline Province & Shanxi & Fujian & Sichuan & Xinjiang & Neimongol \\
\hline Location & Plains & Coastal & Mountains & Plateau & High plateau \\
\hline Diets & $\begin{array}{l}\text { Noodles, } \\
\text { numerous vegetables, } \\
\text { millet, spices }\end{array}$ & $\begin{array}{l}\text { Rice, numerous } \\
\text { vegetables, } \\
\text { fish and } \\
\text { seafood, } \\
\text { pork and } \\
\text { eggs, spices }\end{array}$ & $\begin{array}{l}\text { Rice, sweet potatoes, } \\
\text { corn flour, green } \\
\text { and pickled } \\
\text { vegetables, hot } \\
\text { spices }\end{array}$ & $\begin{array}{l}\text { Wheat bread, milk-tea, } \\
\text { mutton and beef, } \\
\text { potatoes and carrots }\end{array}$ & $\begin{array}{l}\text { Milk-tea, dairy } \\
\text { products, wheat flour, } \\
\text { mutton and beef, } \\
\text { millet }\end{array}$ \\
\hline \multicolumn{6}{|c|}{ Nutrient intakes (per day)* } \\
\hline Energy (MJ) & $8.1 \pm 1.7^{b}$ & $7.5 \pm 1.6^{\mathrm{ab}}$ & $10.8 \pm 3.1^{\mathrm{c}}$ & $6.7 \pm 1.9^{a}$ & $6.9 \pm 1.7^{a}$ \\
\hline Meat fat (g) & $3 \pm 6^{a}$ & $9 \pm 10^{b}$ & $3 \pm 7^{a}$ & $11 \pm 11^{b}$ & $12 \pm 9^{b}$ \\
\hline Dairy fat (g) & $0 \pm 4$ & 0 & 0 & $7 \pm 6$ & $23 \pm 14$ \\
\hline Plant oil (g) & $21 \pm 8^{b}$ & $20 \pm 13^{b}$ & $24 \pm 14^{b}$ & $26 \pm 27^{b}$ & $11 \pm 7^{a}$ \\
\hline Plant protein $(\mathrm{g})$ & $59 \pm 13^{b}$ & $38 \pm 8^{\mathrm{a}}$ & $59 \pm 18^{b}$ & $35 \pm 9^{a}$ & $35 \pm 10^{\mathrm{a}}$ \\
\hline$B$-carotene (RE) & $420 \pm 348^{c}$ & $209 \pm 259^{b}$ & $610 \pm 378^{d}$ & $43 \pm 68^{a}$ & $19 \pm 24^{\mathrm{a}}$ \\
\hline Retinol (RE) & $14 \pm 32^{\mathrm{a}}$ & $36 \pm 39^{a}$ & $11 \pm 22^{a}$ & $59 \pm 96^{a}$ & $507 \pm 760^{b}$ \\
\hline Copper (mg) & $2.3 \pm 0.5^{\mathrm{b}}$ & $1.7 \pm 0.6^{\mathrm{a}}$ & $2.9 \pm 0.8^{\mathrm{c}}$ & $1.5 \pm 0.5^{\mathrm{a}}$ & $2.8 \pm 1.0^{\mathrm{c}}$ \\
\hline
\end{tabular}

*Values are county means \pm SD. Significantly different values at $P<0.05$ within rows by the Tukey-Kramer test have different superscripts. Dairy fat was not tested due to limited data.

\section{INTRODUCTION}

Assessment of vitamin A status is a critical though complex task for nutritionists. Two forms of the vitamin are generally consumed: preformed vitamin A (largely retinyl esters) from animal sources and the provitamin A carotenoids from plant sources. Homeostatic control of plasma retinol concentrations limits the utility of plasma retinol as a general indicator of vitamin A status. Uncertainty about the mechanism and extent of conversion of carotenoids, particularly $B$-carotene, and the association of carotenoids with circulating lipids ${ }^{1,2}$ limits the interpretation of plasma $B$-carotene concentrations in relation to vitamin A status. ${ }^{3}$ Disease states, lipid intake, and seasonal variations in carotenoid consumption also affect plasma vitamin A concentrations. ${ }^{4,5}$ Acute-phase response to infection or trauma, characterized by inflammation and a rise in blood concentrations of C-reactive protein (CRP), commonly affect plasma nutrient concentrations. ${ }^{6}$

In studies largely with American, European, and Japanese subjects, plasma or serum retinol concentrations have been reported to be generally higher in men than women and are positively correlated with alcohol intake, body mass index (BMI), serum triacylglycerol, serum cholesterol, and smoking. ${ }^{1,2,7,8}$ Except occasionally for supplement users, the plasma concentration of retinol is not correlated with intake of either preformed vitamin A or provitamin A carotenoids. ${ }^{1}$ Plasma $B$-carotene concentrations are also positively correlated with plasma cholesterol. ${ }^{1,2}$ In contrast with plasma retinol, plasma $B$-carotene has been reported to be negatively correlated with smoking, plasma triacylglycerol, BMI, and alcohol consumption. ${ }^{1,9,10}$ Plasma $B$-carotene concentrations are generally higher in women and are correlated with the intake of carotenoid-rich foods and specifically with $B$-carotene intake. $^{1}$

Five of the 65 counties originally surveyed in a 1983 ecological study in rural China ${ }^{11}$ were resurveyed in 1989 to study the nutritional causes of osteoporosis in women. ${ }^{12,13}$ The wide range of dietary and lifestyle patterns among these counties made these subjects an ideal group in which to study differing vitamin A nutriture from plant and animal sources. We also report on the physiologic, dietary, and lifestyle factors that are correlates of plasma vitamin A among middle-aged women in these five rural areas of China.

\section{SUBJECTS AND METHODS}

\section{Sampling Procedures}

Details of the field survey including subject selection, a dietary survey, and a health and lifestyle questionnaire have been described previously. ${ }^{12,13}$ Briefly, 5 counties were selected from the original 65 that participated in the 1983 ecological survey. ${ }^{11}$ The county designations, CD, LC, SB, WA, and YA, were the designations in the original study. These sites were chosen to represent a wide variety of dietary patterns that are summarized in Table I. In each county about 150 women between the ages of 32 and 75 were randomly chosen. For this present study a subset of 404 middle-aged women were selected. Excluded were women more than 2 y postmenopausal. Included in the study were 293 women who reported themselves to be premenopausal ranging in age from 32 to 64,63 individuals who reported being 0-2 y postmenopausal, and 48 individuals with incomplete reproductive information, 20 of whom were over $47 \mathrm{y}$, the average age of menopause in these counties. The survey was conducted between September and November 1989.

A detailed 3-d dietary survey was conducted by food weighing on each subject. ${ }^{12}$ A general physical exam was conducted. Weights and heights were recorded and BMIs were calculated. An overnight 12-h urine sample was collected. A fasting blood sample was drawn and plasma was prepared. Plasma and urine samples were shipped on dry ice to Cornell University for analysis. A questionnaire on dietary, reproductive, smoking, and drinking habits was administered. Packs of cigarettes smoked and grams of alcohol consumed per week were recorded. Plasma and urinary cotinine were measured as previously described. ${ }^{13}$ Smokers included the combination of women who either reported smoking or who had high concentrations of plasma cotinine ( $>10 \mathrm{ng} / \mathrm{mL})$ or urinary cotinine $(>100 \mathrm{mg} / 12 \mathrm{~h})$. The smokers of county WA were detected by their cotinine concentrations only and were 
possibly snuff users. ${ }^{11}$ Drinkers were defined as women who reported any alcohol consumption.

The survey protocol was approved by the Human Subject Committee of Cornell University and the Chinese Academy of Preventive Medicine. The experimental protocol was fully explained to the subjects and their signed approval was obtained at the beginning of the survey.

\section{Plasma Analyses}

Plasma samples were stored frozen at $-80^{\circ} \mathrm{C}$ for $4-6$ y and were defrosted for analysis. Others have shown that storage of plasma for $5 \mathrm{y}$ at $-70^{\circ} \mathrm{C}$ is not detrimental to retinol and the carotenoids. ${ }^{14}$ Plasma retinol was measured by modifications of the method of Driskall et al. ${ }^{15}$ Internal standard (retinol acetate) in $600 \mu$,L ethanol was added to a $100-\mu, \mathrm{L}$ sample of plasma and 500 $\mu$,L water and was extracted with $900 \mu$, L hexane. The hexane was evaporated and the sample resuspended with $75 \mu$,L ethanol and then $225 \mu$,L methanol. Duplicate $100-\mu, \mathrm{L}$ injections were made with a Perkin-Elmer ISS-100 model autosampler (Norwalk, CT) onto a model 334 (Beckman Instruments, Cupertino, CA) highpressure liquid chromatograph (HPLC) with an Ultramex $5-\mu, \mathrm{m}$ C-18 4.6 X $250 \mathrm{~mm}$ column (Phenomenex, Inc., Torrance, CA). The mobile phase was methanol with a flow rate of $1.3 \mathrm{~mL} / \mathrm{min}$. A column heater (Timberline, Inc., Boulder, CO) maintained the column at a constant $30^{\circ} \mathrm{C}$. The eluant was monitored at $300 \mathrm{~nm}$ with a Perkin-Elmer model LC-95 detector. Retinol eluted at 3.1 min and retinol acetate at $4.2 \mathrm{~min}$. Plasma concentrations of retinol were calculated by comparison with peak heights of authentic standards and were adjusted for the recovery of the internal standard. The National Institute of Standards and Technology standard reference material 968a (fat soluble vitamins in human serum) was analyzed by this method and the accuracy of the method confirmed. Within the physiologic range the coefficient of variation of the method was $10 \%$.

Plasma $a$-carotene and $B$-carotene were quantified by modification of the preceeding procedure for retinol. The internal standard was echininone and was a gift of Roche, Inc., Nutley, NJ. The sample preparation procedure and the HPLC equipment were the same as for retinol. The HPLC column was an Ultramex $3-\mu, \mathrm{m}$ C-18 4.6 X $250 \mathrm{~mm}$ column with titanium frits. The mobile phase was dichloromethane/acetonitrile/methanol, 20/45/35, with 0.05 $\mathrm{mol} / \mathrm{L}$ ammonium acetate and $0.05 \%$ triethylamine. The flow rate was $1.0 \mathrm{~mL} / \mathrm{min}$. The detector was set at $450 \mathrm{~nm}$. $a$-Carotene eluted at $10.2 \mathrm{~min}, B$-carotene at $10.6 \mathrm{~min}$, a small cis $B$-carotene peak at $11.1 \mathrm{~min}$, and the internal standard at $6.4 \mathrm{~min}$. Verification of the accuracy of the method was similar to retinol. When analyzing the standard reference material $968 \mathrm{a}$, recovery of $B$-carotene averaged $85 \%$. Within the physiologic range of concentrations the coefficient of variation for $B$-carotene was $11 \%$.

Plasma albumin was measured with Sigma Chemical kit 631 (St. Louis, MO) using the bromcresol green binding principle. Each sample was measured in triplicate and the median value used in the calculations. Analysis of a certified sample (Sigma M3366) verified the accuracy of the assay. The coefficient of variation was $5 \%$. Plasma cholesterol was measured with Sigma kit 352, by the cholesterol oxidase-peroxidase method, with verification using Sigma certified sample C7921. The coefficient of variation was $6 \%$.

Plasma copper was measured by the method of Abe et al., ${ }^{16}$ which involved selective and quantitative binding of $\mathrm{Cu}^{2+}$ to the chromogen, 4-(3,5-dibromo-2-pyridylazo)- $N$-ethyl- $N$-sulfopropylaniline. The National Institute of Standards and Technology standard reference material 1598 (inorganic constituents in bovine serum) was found by this method to be $34 \%$ above the certified value. The coefficient of variation in the physiologic range was $17 \%$.
Retinol-binding protein (RBP), apolipoprotein B (ApoB), ceruloplasmin, and CRP were measured by automated nephelometry using a Behring Diagnostics model BN100 (Somerville, NJ). The accuracy of these methods was confirmed using Behring N/T CRP Control Serum, N/T Protein Control Serum, Apolipoprotein Control Serum CHD, and BioRad Liquichek (Hercules, CA). The coefficient of variations were $6 \%$ for RBP, $3 \%$ for ceruloplasmin, and $5 \%$ for ApoB. Over a wide range of CRP titers the coefficient of variation was about $10 \%$.

\section{Statistics}

The data were analyzed using Systat 5.03 statistical software (Evanston, IL). County means were compared by the TukeyKramer post-hoc multiple comparisons test. The tabulation of subjects was tested for significance by Chi-squared. Linear regression models were always performed with county of residence as a variable.

The farming counties (CD, LC, and SB) exhibited similar lifestyles, diets, and particularly dietary vitamin A sources. Data from these counties were combined for multiple linear models in the assessment of nutrient status. Plasma $a$ - and $B$-carotene values were $\log$ transformed. Both plasma carotenes exhibited skewed distributions that were substantially normalized by this operation. In models with menopausal status as a variable, subjects with no indicated menopausal status (48 subjects) and women who declared themselves to be premenopausal but were over 55 y old (4 subjects) were excluded from the analysis.

\section{RESULTS}

The principal diets of the five survey counties are described in Table I. Total energy intake in MJ $(0.0042 \mathrm{MJ} / \mathrm{kcal})$ generally reflected physical work activities. Energy intakes were highest in the farming counties, in Shanxi province (CD), Fijian province (LC), and Sichuan province (SB). Intakes were lower and more comparable to average American levels in the pastoral survey areas in Xinjiang province (WA) and Neimongol province (YA). Differing intakes of meat and dairy fat reflect the wide diversity of dietary patterns in these counties. Meat and dairy protein intakes from these sources closely resembled fat intake (data not shown).

Vegetable oil (usually rapeseed oil) was widely used, though lower in Neimongol, and was not correlated to the consumption of other plant products. Plant protein consumption was the inverse of meat consumption. Carbohydrate consumption was high in the farming areas, especially Sichuan, where plant-based energy intake from protein and carbohydrates comprised $90 \%$ of total energy consumption (compared with $56 \%$ in the USA).

Total vitamin A intake was low to moderate across the survey counties. $B$-carotene was the predominant form of dietary vitamin $\mathrm{A}$ in the farming areas, $94 \%$ of the total retinol equivalents (RE), although mean consumption was equivalent to only $55 \%$ of the Chinese and American recommended daily allowances (RDA) of $800 \mathrm{RE} / \mathrm{d}$. Preformed vitamin A from dairy sources was the predominant form in county YA ( $80 \%$ of the total RE). County WA, with low intakes both of dairy and vegetable foods, was low in both forms of the vitamin with a mean daily consumption of only 102 RE. In the five counties, the major dietary sources of provitamin-A carotenoids were carrots, fresh and pickled Chinese cabbage, fresh and dried sweet potatoes, and dried chili peppers. Dietary preformed vitamin A was most often provided by goat liver, milk, and milk products (data not shown).

Table II summarizes plasma constituents and Table III summarizes other nutritional, disease, and lifestyle characteristics of the women. Plasma retinol concentrations were generally in the expected range for middle-aged women, though average concentrations were lower in counties SB and WA where the incidence of marginally low plasma retinol (defined as a plasma retinol 
TABLE II.

CONCENTRATIONS OF SELECTED PLASMA CONSTITUENTS OF CHINESE WOMEN IN FIVE RURAL COUNTIES*

\begin{tabular}{|c|c|c|c|c|c|}
\hline & \multicolumn{5}{|c|}{ County } \\
\hline & $\mathrm{CD}$ & $\mathrm{LC}$ & SB & WA & YA \\
\hline Retinol $(\mu, \mathrm{mol} / \mathrm{L})$ & $1.34 \pm 0.30^{\mathrm{ab}}$ & $1.56 \pm 0.38^{\mathrm{c}}$ & $1.27 \pm 0.33^{\mathrm{ab}}$ & $1.22 \pm 0.34^{\mathrm{a}}$ & $1.38 \pm 0.31^{\mathrm{b}}$ \\
\hline $\mathrm{RBP}(\mathrm{mg} / \mathrm{L})$ & $28 \pm 7^{b}$ & $31 \pm 8^{\mathrm{b}}$ & $26 \pm 7^{a}$ & $23 \pm 7^{a}$ & $29 \pm 7^{b}$ \\
\hline$B$-carotene $(\mu, \mathrm{mol} / \mathrm{L})$ & $0.28 \pm 0.15^{\mathrm{bc}}$ & $0.66 \pm 0.54^{\mathrm{d}}$ & $0.40 \pm 0.24^{\mathrm{c}}$ & $0.16 \pm 0.23^{\mathrm{ab}}$ & $0.13 \pm 0.07^{\mathrm{a}}$ \\
\hline Albumin (g/L) & $52 \pm 6^{\mathrm{c}}$ & $51 \pm 5^{\mathrm{c}}$ & $49 \pm 5^{b}$ & $48 \pm 5^{\mathrm{ab}}$ & $46 \pm 5^{a}$ \\
\hline Cholesterol (mmol/L) & $3.7 \pm 0.9^{a}$ & $4.3 \pm 1.0^{\mathrm{b}}$ & $3.8 \pm 0.7^{a}$ & $3.8 \pm 0.8^{\mathrm{a}}$ & $4.6 \pm 0.9^{b}$ \\
\hline ApoB $(\mathrm{mg} / \mathrm{L})$ & $593 \pm 137^{\mathrm{ac}}$ & $655 \pm 187^{\mathrm{c}}$ & $548 \pm 137^{a}$ & $578 \pm 194^{\mathrm{ab}}$ & $632 \pm 156^{b c}$ \\
\hline Copper $(\mu, \mathrm{mol} / \mathrm{L})$ & $15 \pm 4^{\mathrm{ab}}$ & $14 \pm 4^{\mathrm{a}}$ & $15 \pm 6^{\mathrm{ab}}$ & $16 \pm 5^{\mathrm{b}}$ & $16 \pm 5^{\mathrm{b}}$ \\
\hline Ceruloplasmin (mg/L) & $338 \pm 78^{a}$ & $347 \pm 120^{\mathrm{a}}$ & $314 \pm 82^{a}$ & $427 \pm 131^{b}$ & $399 \pm 119^{b}$ \\
\hline $\mathrm{CRP}(\mathrm{mg} / \mathrm{L})$ & $8 \pm 23^{a}$ & $10 \pm 27^{a}$ & $10 \pm 38^{\mathrm{a}}$ & $31 \pm 76^{b}$ & $5 \pm 9^{a}$ \\
\hline
\end{tabular}

* Values are means \pm SD. Significantly different values at $P<0.05$ within rows by the Tukey-Kramer test have different superscripts.

ApoB, apolipoprotein B; CRP, C-reactive protein; RBP, retinol-binding protein

value $<0.7 \mu, \mathrm{mol} / \mathrm{L})$ was elevated. Plasma $B$-carotene concentrations reflected Western and Japanese values for counties LC and $\mathrm{SB}$, whereas the remaining counties were markedly lower particularly in the pastoral counties WA and YA, where B-carotene consumption was very low.

Plasma cholesterol was generally below $5 \mathrm{mmol} / \mathrm{L}(193 \mathrm{mg} /$ $\mathrm{dL}$ ). The percent of subjects with values over $5 \mathrm{mmol} / \mathrm{L}$ were highest in county YA and lowest in county SB. CRP showed considerable variation between counties. Values were relatively high in county WA compared with other counties. Distributions of CRP within counties were highly skewed with many undetectable concentrations and a few individuals with values over $50 \mathrm{mg} / \mathrm{L}$. County average concentrations of albumin and copper were rather uniform among these counties despite wide variation among individuals. Ceruloplasmin concentrations paralleled cholesterol and $\mathrm{ApoB}$ concentrations across counties.
The consumption of alcoholic beverages was low in rural China and only 1 subject reported smoking more than 1 pack of cigarettes per day. The subjects were relatively lean compared with American women. The percent of subjects classified as overweight, with BMI over 25 , varied from a low of $1 \%$ in county SB to a high of $27 \%$ in county CD.

High concentrations of CRP corresponded to an increased incidence of marginally low plasma retinol concentrations (Table IV). One-third of the women with CRP concentrations greater than $100 \mathrm{had}$ values of plasma retinol below $0.7 \mu, \mathrm{mol} / \mathrm{L}$, whereas only $1 \%$ of women with normal concentrations of CRP had low plasma retinol concentrations. Ceruloplasmin, a positive acute-phase reactant, and plasma $B$-carotene were also significantly different in higher CRP groups (Table V). Plasma RBP and albumin were only slightly decreased in the high-CRP group (data not shown). Among subjects with marginally low plasma retinol concentra-

TABLE III.

LIFESTYLE AND PHYSIOLOGIC CHARACTERISTICS OF CHINESE WOMEN IN FIVE RURAL COUNTIES

\begin{tabular}{|c|c|c|c|c|c|}
\hline & \multicolumn{5}{|c|}{ County } \\
\hline & $\mathrm{CD}$ & $\mathrm{LC}$ & SB & WA & YA \\
\hline $\operatorname{Age}^{*}(\mathrm{y})$ & $43 \pm 5$ & $43 \pm 6$ & $44 \pm 7$ & $43 \pm 6$ & $43 \pm 6$ \\
\hline Drinkers $(\%)$ & 0 & 2 & 21 & 0 & 3 \\
\hline Alcohol intake $\dagger(\mathrm{g} / \mathrm{wk})$ & - & 52 & 55 & - & 217 \\
\hline Smokers $(\%)$ & 34 & 0 & 14 & 9 & 42 \\
\hline Smoking $(\mathrm{pk} / \mathrm{wk}) \dagger$ & 1.7 & - & 2.0 & - & 3.5 \\
\hline High cholesterol $(\%>5 \mathrm{mmol} / \mathrm{L})$ & 8 & 15 & 4 & 10 & 28 \\
\hline High CRP (\% ;:: 50 mg/L) & 3 & 5 & 5 & 13 & 0 \\
\hline $\mathrm{BMI}+\left(\mathrm{kg} / \mathrm{m}^{2}\right)$ & $23.6 \pm 3.5^{\mathrm{c}}$ & $21.3 \pm 3.3^{\mathrm{ab}}$ & $20.2 \pm 2.1^{\mathrm{a}}$ & $22.8 \pm 3.6^{\mathrm{c}}$ & $22.4 \pm 2.9^{b c}$ \\
\hline Overweight $\left(\%>25 \mathrm{~kg} / \mathrm{m}^{2}\right)$ & 27 & 14 & 1 & 22 & 19 \\
\hline Low plasma retinol $(\%<0.7 \mu, \mathrm{mol} / \mathrm{L})$ & 0 & 1 & 5 & 6 & 1 \\
\hline
\end{tabular}

* Mean \pm SD. Average age was not significantly different between counties.

$\uparrow$ Alcohol intake and smoking are median values among drinkers only or smokers only.

\pm Mean \pm SD. BMI values with different superscripts are statistically different at $P<0.05$ using the Tukey-Kramer test.

$\mathrm{BMI}$, body mass index; CRP, C-reactive protein. 
TABLE IV.

\begin{tabular}{lcc}
\hline C-REACTIVE PROTEIN (CRP) AND VITAMIN A DEFICIENCY \\
\hline Plasma & & $\begin{array}{c}\% \text { Subjects } \\
\text { with plasma }\end{array}$ \\
CRP & No. \\
$(\mathrm{mg} / \mathrm{L})$ & subjects & $\mu, \mathrm{mol} / \mathrm{L}$ \\
\hline 0 & 198 & $1 * 7$ \\
$1-100$ & 152 & 4 \\
$;: 100$ & 9 & 33 \\
\hline
\end{tabular}

* Differences in percentage incidence are significant by Chi-squared to $P<0.001$

tions, CRP concentrations are also significantly elevated $(P<$ 0.001 , data not shown) and plasma retinol and CRP concentrations are inversely correlated $(r=-0.15, P<0.001)$.

Plasma retinol and retinol-binding protein-carotene concentrations were compared with several diet and lifestyle indicators (Table VI). Only data from the three farming counties (CD, LC, and SB) were utilized and controlled for in these linear models. The predominant source of vitamin $\mathrm{A}$ in these counties was $B$ carotene and the levels of animal products (including preformed vitamin A) in the diet were low in all three counties. Plasma cholesterol was positively correlated with plasma retinol, $B$-carotene, and $a$-carotene. Controlling for age, plasma retinol was higher in women who were 1-2 y postmenopausal compared with those who were premenopausal, whereas $a$ - and $B$-carotene were lower in 1-2 y postmenopausal individuals. After adjusting for plasma cholesterol and survey county, plasma retinol did not correlate with smoking, drinking, or age, or with the consumption of preformed retinol or $B$-carotene (data not shown).

A limited number of linear models were examined with regard to correlates of plasma retinol (Table VII, Table VIII). Among the farming counties plasma retinol was predicted by a linear combination of survey county, plasma $B$-carotene, plasma cholesterol, plasma copper, menopausal status, and age (Table VII). Plasma copper concentration was itself correlated with the intake of copper $(P=0.007)$. Plasma $B$-carotene, in the farming counties, was predicted by a linear combination of county, plasma choles-

TABLE V.

\begin{tabular}{lccc}
\hline \multicolumn{4}{c}{ C-REACTIVE PROTEIN (CRP) AND OTHER ACUTE-PHASE } \\
REACTANTS*
\end{tabular}

* Statistics for plasma $B$-carotene were performed using logarithm-transformed values. Values shown are untransformed group means. Values within columns with different letter superscripts were significantly different at $P<0.05$ using the Tukey test. The number of subjects in each CRP subgroup is the same as for Table IV.
TABLE VI

CORRELATES OF PLASMA RETINOL, B-CAROTENE, AND a-CAROTENE IN FARMING COUNTIES

\begin{tabular}{|c|c|c|c|}
\hline Variable & $\begin{array}{l}\text { Retinol* } \\
(\mu, \mathrm{mol} / \mathrm{L})\end{array}$ & $\begin{array}{c}B \text {-Carotene* } \\
(\mu, \mathrm{mol} / \mathrm{L})\end{array}$ & $\begin{array}{c}\text { a-Carotene* } \\
(\mu, \mathrm{mol} / \mathrm{L})\end{array}$ \\
\hline $\begin{array}{l}\text { Plasma cholesterol } \\
\quad(\mathrm{mmol} / \mathrm{L})\end{array}$ & $\begin{array}{l}+0.093^{\dagger} \\
P=0.001\end{array}$ & $\begin{array}{c}+0.164 \\
P=0.002\end{array}$ & $\begin{array}{c}+0.162 \\
P<0.001\end{array}$ \\
\hline $\begin{array}{l}\text { Postmenopausal } \$ \\
\quad(\text { no }=0 \\
\text { yes }=1)\end{array}$ & $\begin{array}{c}+0.165 \\
P=0.028\end{array}$ & $\begin{array}{c}-0.243 \\
P=0.001\end{array}$ & $\begin{array}{c}-0.120 \\
P=0.031\end{array}$ \\
\hline $\begin{array}{l}\text { Plasma retinol } \\
(\mu, \mathrm{mol} / \mathrm{L})\end{array}$ & - & $\begin{array}{c}+0.251 \\
P=0.061\end{array}$ & $\begin{array}{c}+0.277 \\
P=0.006\end{array}$ \\
\hline
\end{tabular}

* Logarithmically transformed data were used for these variables.

$\dagger$ Values are linear model coefficients with only county and the row variable predicting the column variable. The associated partial $P$ value is for the row variable in that model.

$\$$ Age was also included in the linear model with the dichotomous variable for menopause.

terol, plasma CRP, menopausal status, and age. Either before or after controlling for these independent predictors of plasma $B$-carotene, no measurement of nutrient intake, including dietary fiber, lipid, vitamin $\mathrm{C}$, or $B$-carotene was significantly correlated with plasma $B$-carotene (data not shown).

Among the farming counties, plasma cholesterol was predicted by county, age, BMI, lipid intake, and animal protein consumption. The intake of lipid from either animal or plant sources showed similar moderately inverse effects in this model (data not shown) as did total lipid consumption.

In contrast to the farming counties, among the pastoral counties (WA and YA) with very low $B$-carotene intake and relatively high consumption of animal products, plasma retinol was not correlated with plasma $B$-carotene nor with menopausal status and was negatively correlated with plasma CRP concentration (Table VIII).

\section{DISCUSSION}

Vitamin A consumption among this female cohort in rural China was relatively low compared with the reported female American and European average daily consumption of $400 \mathrm{RE}$ of $B$-carotene and $900 \mathrm{RE}$ of preformed vitamin A. ${ }^{17,18}$ Mean total vitamin A consumption was about $50 \%$ of the RDA for all the study areas together. Individuals in county WA consumed only $102 \mathrm{RE} / \mathrm{d}$ of total vitamin A ( $13 \%$ of the RDA) with only $59 \mathrm{RE} / \mathrm{d}$ from preformed vitamin A. Surprisingly, only $6 \%$ of the WA subjects had marginally low plasma retinol concentrations of less than $0.7 \mu, \mathrm{mol} / \mathrm{L}$, and plasma retinol was not correlated with intake of either preformed or provitamin A. The relatively high consumption of total lipids compared with the other counties, at $25 \%$ of energy, may facilitate vitamin A absorption in this county.

This survey was conducted during the harvest season of September to November. This was a cross-sectional survey and one concern might be that food consumption in the season of the survey may not reflect year-round consumption of vitamin-A-rich foods. From the 1983 ecologic study of food consumption in 65 rural counties ${ }^{11,19}$ and from a similar study in 1989 (unpublished), the average year-round consumption of carotenoid-rich foods was a little less than one serving per day. These foods were generally staple foods available year-round and included dried and fresh sweet potato, carrots, and pickled Chinese cabbage. Preformed vitamin A, largely available from liver and dairy products, was 
TABLE VII.

LINEAR MODELS OF DETERMINANTS OF PLASMA RETINOL IN FARMING COUNTIES ONLY*

\begin{tabular}{|c|c|c|c|c|}
\hline \multirow[b]{2}{*}{ Independent variables } & \multicolumn{2}{|c|}{ Univariate } & \multicolumn{2}{|c|}{ Multivariate } \\
\hline & $r$ & $P$ & $B$ & $P$ \\
\hline \multicolumn{5}{|c|}{ Dependent variable: Plasma retinol $(\mu, \mathrm{mol} / \mathrm{L})$} \\
\hline County & - & $<0.001$ & - & 0.001 \\
\hline Plasma $B$-carotene $\dagger$ & 0.22 & 0.002 & 0.064 & 0.084 \\
\hline Plasma cholesterol & 0.31 & $<0.001$ & 0.056 & 0.044 \\
\hline Plasma copper & 0.19 & 0.007 & 0.016 & $<0.001$ \\
\hline Menopause $\ddagger$ & 0.08 & 0.225 & 0.155 & 0.035 \\
\hline Age & -0.10 & 0.150 & -0.012 & 0.007 \\
\hline & & & $\mathrm{R}^{2}=0.22$ & $(P<0.001)$ \\
\hline \multicolumn{5}{|c|}{ Dependent variable: Plasma $B$-carotene $(\log$ of $\mu, \mathrm{mol} / \mathrm{L})$} \\
\hline County & - & $<0.001$ & - & $<0.001$ \\
\hline Plasma cholesterol & 0.29 & $<0.001$ & 0.186 & $<0.001$ \\
\hline Plasma CRP\$ & -0.23 & 0.001 & -0.208 & $<0.001$ \\
\hline Menopause & -0.19 & 0.006 & -0.247 & $<0.001$ \\
\hline Age & -0.12 & 0.084 & 0.004 & 0.592 \\
\hline & & & $\mathrm{R}^{2}=0.33$ & $(P<0.001)$ \\
\hline \multicolumn{5}{|c|}{ Dependent variable: Plasma cholesterol (mmol/L) } \\
\hline County & - & $<0.001$ & - & 0.082 \\
\hline Age & 0.10 & 0.150 & 0.017 & 0.104 \\
\hline Body mass index & 0.04 & 0.530 & 0.035 & 0.073 \\
\hline Dietary lipid & -0.03 & 0.644 & -0.009 & 0.047 \\
\hline \multirow[t]{2}{*}{ Dietary animal protein } & 0.28 & $<0.001$ & 0.032 & 0.003 \\
\hline & & & $\mathrm{R}^{2}=0.14$ & $(P=0.05)$ \\
\hline
\end{tabular}

* Approximately 222 subjects in each model.

$\dagger$ Logarithm transformed.

$\ddagger$ pre $=0$, post $=1$.

$\S$ Square root transformed.

CRP, C-reactive protein.

also generally available year-round but in a limited geographic area. Therefore, there appears to be very little seasonality bias to the vitamin A intake data. The adequacy of carotenoids as sources of vitamin A has been questioned recently. ${ }^{20,21}$ The indications from the farming counties of this survey were that in these counties where preformed vitamin A intake was extremely low, carotenoid-rich foods provided adequate sources of vitamin A.

Subjects with moderate or high concentrations of CRP were significantly more likely to have marginally low concentrations of plasma retinol. In response to infection or other trauma, plasma concentrations of a number of proteins and other constituents are altered within a day or two. Previous studies have shown that acute-phase response leads to decreases in plasma concentrations of carotenes, albumin, retinol, RBP, copper, and cholesterol and increases in ceruloplasmin. ${ }^{6,22} \mathrm{We}$ confirmed a negative correlation between CRP and plasma $B$-carotene and retinol, and a positive correlation with ceruloplasmin, but fail to find a significant association with cholesterol, ApoB, albumin, RBP, or copper. These results suggest that the acute-phase response seen in some subjects may have caused a decrease in plasma levels of retinol and $B$-carotene and further suggests that apparent vitamin $\mathrm{A}$ deficiencies in rural China may be due in part to the acute-phase response and not low vitamin A intake. However, a role for low vitamin A status in causing infection and inflammation cannot be ruled out based on this cross-sectional study.

There was no correlation between $B$-carotene consumption and
TABLE VIII.

LINEAR MODELS OF DETERMINANTS OF PLASMA RETINOL IN PASTORAL COUNTIES ONLY*

\begin{tabular}{|c|c|c|c|c|}
\hline \multirow[b]{2}{*}{ Independent variables } & \multicolumn{2}{|c|}{ Univariate } & \multicolumn{2}{|c|}{ Multivariate } \\
\hline & $r$ & $P$ & $B$ & $P$ \\
\hline \multicolumn{5}{|c|}{ Dependent variable: Plasma retinol $(\mu, \mathrm{mol} / \mathrm{L})$} \\
\hline County & - & 0.002 & - & 0.251 \\
\hline Plasma cholesterol & 0.36 & $<0.001$ & 0.107 & 0.002 \\
\hline Plasma copper & 0.13 & 0.098 & 0.010 & 0.068 \\
\hline \multirow[t]{2}{*}{ Plasma CRP $\dagger$} & -0.27 & 0.001 & -0.019 & 0.020 \\
\hline & & & $\mathrm{R}^{2}=0.20$ & $(P=0.001)$ \\
\hline
\end{tabular}

$* N=141$.

$\dagger$ Square root transformed.

plasma $B$-carotene concentrations. This is in contrast to many previous reports with subjects from more economically developed regions of the world in which positive correlations have been reported before and after controlling for confounders such as sex, age, and plasma cholesterol. ${ }^{23,24}$ In the present study no measured dietary parameters, including dietary fiber, lipids, retinol, copper, or vitamin $\mathrm{C}$, were significantly correlated with plasma $B$-carotene. This unusual finding may be related to the cross-sectional nature of this study. However, cross-sectional studies in the United States that demonstrated a strong correlation $(r=0.41-$ 0.51 ) between intakes and plasma levels of $B$-carotene used semiquantitative food frequency questionnaires and 7-d food records. ${ }^{23,24}$ This lack of correlation in rural China may also be due to intestinal conversion of dietary $B$-carotene to retinol. In populations for which the major source of vitamin $A$ is $B$-carotene, the plasma $B$-carotene concentration, roughly approximating liver storage levels of $B$-carotene, might be expected to be lower in individuals with a higher intestinal conversion of $B$-carotene to retinol and hence a possibly more normal plasma retinol level. Conversely, the high correlation among women with high intakes of both preformed and provitamin A in the United States may reflect a lack of intestinal conversion of $B$-carotene to retinol.

Despite these limitations and complications, these results suggest that plasma $B$-carotene concentrations, in context of the dietary and lifestyle conditions in rural China, are influenced less by extrinsic factors, such as diet and lifestyle, and more by intrinsic factors, possibly including physiologic or pathologic factors affecting overall vitamin A status. What those intrinsic factors are is still unclear but our results suggest that they may include vitamin A requirements, hormonal factors related to menopause, factors affecting acute-phase response, and factors affecting lipid status as reflected by plasma cholesterol.

Our study was focused on premenopausal and recently menopausal women. After controlling for age and county of residence, we found that postmenopausal women had $10 \%$ higher plasma retinol and $40 \%$ lower $B$-carotene than premenopausal women. Adult women generally have lower plasma retinol and higher plasma $B$-carotene concentrations than men. ${ }^{17,18,25}$ Our results suggest that within 2 y of menopause, the gender differences in plasma retinol and $B$-carotene disappear in a population dependent on carotenoids as their source of vitamin A.

The finding that plasma copper was positively and independently correlated with plasma retinol in this ecologic study has not been previously reported to our knowledge. In contrast, Tebi et al. ${ }^{26}$ have reported an inverse correlation in elderly subjects. 
Animal studies have shown that feeding diets deficient in copper leads to reduced retinol concentrations. ${ }^{27}$ However, in human studies plasma copper is generally not correlated with copper intake. ${ }^{28}$ In this study we found a correlation between the intake of plant sources of copper and plasma copper concentrations in the three farming counties. These results suggest that under the dietary and lifestyle conditions in rural China, plasma copper concentration may reflect intake and may affect plasma retinol in a manner similar to the animal studies ${ }^{27}$ and in contrast to the previous human studies. ${ }^{26,28}$

Unlike most Westerners, most rural Chinese rely on carotenoids as their major dietary source of vitamin A. Various individual differences in physiologic factors, such as the efficiency of conversion of $B$-carotene to retinol, vitamin A requirements and metabolism, carotene mobilization in low-density lipoproteins, and possibly heightened states of acute-phase response, may override differences in $B$-carotene intake as predictors of plasma $B$ carotene concentrations. Nonetheless, among these women, dietary $B$-carotene was an adequate source of vitamin A nutriture even in the context of relatively high fiber intake and low fat intake relative to Western populations. Further research is needed to determine the extent to which other environmental and dietary factors or physiologic and pathologic factors may play a role in vitamin A nutrition in rural China.

\section{ACKNOWLEDGMENTS}

The authors acknowledge the valuable technical assistance of Heather Delans, Jean Chung, Marie Drake, Yi-An Lee, and Eva Revesz.

\section{REFERENCES}

1. Roidt L, White E, Goodman GE, et al. Association of food frequency questionnaire estimates of vitamin A intake with serum vitamin A levels. Am J Epidemiol 1988;128:645

2. Herbeth B, Didelot-Barthelemy L, Le Devehat C, Lemoine A. Rétinol, caroténoïdes et tocophérols plasmatiques: facteurs de variation biologique entre 18 et 45 ans. Ann Nutr Metab 1988;32:297

3. Olson JA. Serum levels of vitamin A and carotenoids as reflectors of nutritional status. J Natl Cancer Inst 1984;73:1439

4. Ruz M, Solomons N, Mejia LA, Che F. Alteration of circulating micronutrients with overt and occult infections in anaemic Guatemalan preschool children. Int J Food Sci Nutr 1995;46:257

5. Cooney RV, Franke AA, Hankin JH, et al. Seasonal variations in plasma micronutrients and antioxidants. Cancer Epidemiol Biomarkers Prev 1995;4:207

6. Louw JA, Werbeck A, Louw MEJ, et al. Blood vitamin concentrations during the acute-phase response. Crit Care Med 1992;20:934

7. Pamuk ER, Byers T, Coates RJ, et al. Effect of smoking on serum nutrient concentrations in African-American women. Am J Clin Nutr 1994;59:891

8. Aoki K, Ito Y, Sasake R, et al. Smoking, alcohol drinking and serum carotenoids levels. Jpn J Cancer Res 1987;78:1049

9. Hercberg S, Preziosi P, Galan P, et al. Vitamin status of a healthy French population: dietary intakes of biochemical markers. Int $\mathrm{J}$ Vitamin Nutr Res 1994:64:220

10. Ascherio A, Stampfer MJ, Colditz GA, et al. Correlations of vitamin $\mathrm{A}$ and $\mathrm{E}$ intakes with the plasma concentrations of carotenoids and tocopherols among American men and women. J Nutr 1992;122:1792

11. Chen J, Campbell TC, Li J, Peto R. Diet, lifestyle, and mortality in China. Oxford, Ithaca, Beijing: Oxford University Press, Cornell University Press, People's Medical Publishing House, 1991

12. Hu J-F, Zhao X-H, Jia J-B, Parpia B, Campbell TC. Dietary calcium and bone density among middle-aged and elderly women in China. Am J Clin Nutr 1993a;58:219

13. Hu J-F, Zhao X-H, Chen J-S, et al. Bone density and lifestyle characteristics in premenopausal and postmenopausal Chinese women. Osteoporos Int 1994a;4:288

14. Edmonds BK, Nierenberg DW. Serum concentrations of retinol, $d$ - $a$ tocopherol and $B$-carotene: effects of storage at $-70^{\circ} \mathrm{C}$ for five years. J Chrom 1993;614:169

15. Driskall WJ, Neese JW, Bryant CC, Bashor MM. Measurement of vitamin $\mathrm{A}$ and vitamin $\mathrm{E}$ in human serum by high-performance liquid chromatography. J Chrom 1982;231:439

16. Abe A, Yamashita S, Noma A. Sensitive direct colorimetric assay for copper in serum. Clin Chem 1989;35:552

17. Hebert JR, Hurley TG, Hsieh J, et al. Determinants of plasma vitamins and lipids: the Working Well Study. Am J Epidemiol 1994;140:132

18. Kardinaal AFM, van't Veer P, Brants HAM, et al. Relations between antioxidant vitamins in adipose tissue, plasma, and diet. Am J Epidemiol 1995; 141:440

19. Wang G, Brun TA, Geissler CA, et al. Vitamin A and carotenoid status in rural China. Br J Nutr 1996;76:809

20. de Pee S, West CE, Muhilal, Karyadi D, Hautvast JGAJ. Lack of improvement in vitamin A status with increased consumption of dark-green leafy vegetables. Lancet 1995;346:75

21. de Pee S, West C. Dietary carotenoids and their role in combating vitamin A deficiency: a review of the literature. Eur J Clin Nutr 1996;50:S38

22. Rettmer RL, Williamson JC, Labbe RF, Heimbach DM. Laboratory monitoring of nutritional status in burn patients. Clin Chem 1992;38: 334

23. Yong L-C, Forman MR, Beecher GR, et al. Relationship between dietary intake and plasma concentrations of carotenoids in premenopausal women: application of the USDA-NCI carotenoid food-composition database. Am J Clin Nutr 1994;60:223

24. Stryker WS, Kaplan LA, Stein EA, et al. The relationship of diet, cigarette smoking, and alcohol consumption to plasma beta-carotene and alpha-tocopherol levels. Am J Epidemiol 1988;127:283

25. Comstock GW, Menkes MS, Schober SE, Vuilleumier J-P, Helsing KJ. Serum levels of retinol, beta-carotene, and alpha-tocopherol in older adults. Am J Epidemiol 1988;127:114

26. Tebi A, Chau N, Debry G, Cuny G. Le zinc et le cuivre plasmatiques chez les personnes âgées hospitalisées: relations avec l'état nutritionnel et le statut immunitaire: etude de cas témoins. Annales Médicales ce Nancy et de l'Est 1988;27:397

27. Rachman F, Conjat F, Carreau JP, Bleiberg DF, Amedee M. Modification of vitamin A metabolism in rats fed a copper-deficient diet. Int J Vitamin Nutr Res 1987:57:247

28. Strain JJ. Newer aspects of micronutrients in chronic disease: copper. Proc Nutr Soc 1994:53:583 